\title{
An accounting system to support process improvements: Transition to lean accounting
}

\author{
Patxi Ruiz de Arbulo-López ${ }^{1}$, Jordi Fortuny-Santos ${ }^{2}$ \\ ${ }^{1}$ Universidad del País V asco (SP AIN); ${ }^{2}$ Universitat Politecnica de Catalunya (SPAIN) \\ patxi.ruizdearbulo@,ehu.es;jordi.fortuny@,upc.edu
}

Received February 2010

Accepted November 2010

\begin{abstract}
From the last two decades of the 20th Century on, many companies have adopted production strategies that could be termed "lean manufacturing". Lean team leaders state that traditional costing systems fail to properly assess their operational improvements and therefore ask for new cost accounting methods. The search for a new accounting paradigm has led to important applied research and several accounting methods. In this paper we are going to show the state of the art in costing techniques used in companies that adopt lean manufacturing practices and we will be presenting an additional costing method, based on Activity-Based Costing, intended to cast light on the operational improvements achieved in companies that are just starting a maturity path towards lean manufacturing. This article examines how the approach is applied in the context of a manufacturing company.
\end{abstract}

Keywords: lean manufacturing, lean accounting, Activity-Based Costing

\section{New cost accounting paradigms}

The first objective of this paper is to present state-of-the-art uses of costing techniques to assess process improvements. Companies adopt lean manufacturing strategies (Sugimori, Kusunoki, Cho, \& Uchikawa, 1977; Womack \& Jones, 1996) in search of improvements in productivity, quality, flexibility, delivery speed and cost (Womack, Jones, \& Ross, 1990; Sriparavastu \& Gupta, 1997). However, those 
companies may find that lean practices lead to operational improvements but they do not "hit the bottom-line" because there are neither short-term financial benefits nor product cost reductions. This fact can act as a disincentive to change the production system (Ahlström \& Karlsson, 1996). In The Goal (Goldratt \& Cox, 1986) there is an example of the fact that a simple manufacturing improvement based on the reduction of the transfer batch size between workstations leads to an apparent increase in per unit product cost (Equation 1) even though the plant operating cost (operating expense according to Goldratt) has not gone up. This is only true while there is unused capacity, but the costing system ignores whether there is or not and assumes that extra work always needs extra labor).

$$
\text { Cost }_{\text {per unit }}=\left(\frac{\text { Setup time }}{\text { Batch size }}+\text { process time }\right) \cdot \text { Labor rate } \cdot(1+\text { overhead apportionment })
$$

Equation 1. "The influence of batch size on the cost of pieces according to traditional cost accounting". Based on Goldratt and Cox (1986)

In consequence, Goldratt and Cox (1986) state that cost accounting is the number one enemy of productivity and they put forward their own accounting approach termed throughput accounting.

In a similar way, a reduction in inventories of finished products results in an increase in costs and therefore in a reduction of profit. Table 1 shows such a situation. Till period $n-1$, the company produces in order to meet warehouse inventory needs. In period $n$, with the same sales figures, manufacturing is adjusted to net demand and, by the end of the period, the warehouse is empty. In that period, manufacturing capacity is not used to the full, and fixed production costs are the same as in previous periods. In consequence, the cost of the product apparently increases. According to cost reports such as Table 1, transition to lean manufacturing yields an increase in product cost, a reduction in productivity, a diminution in a current asset (inventories), and a reduction in profit (or even financial losses). In this example, incurred fixed production costs (wages) are allocated to products; if a predetermined rate was used, the cost of the products would not be different from the one in period $n$. The under absorbed incurred cost would be considered as the cost of unused capacity and the final profit would be 500: In order to get rid of inventories, workers have produced less and a part of the incurred (fixed) cost has not yielded any earnings. 
In period $n+1$, keeping production adjusted to demand, transitory costs caused by misused capacity cease and the company returns to financial benefits, but in the meantime, people responsible for the transition to lean manufacturing have to justify the results to their managers (Olivella, 2008).

\begin{tabular}{|c|c|c|c|}
\hline Term & n-1 & $\mathbf{n}$ & $n+1$ \\
\hline Initial inventory position (pieces) & 50 & 50 & 0 \\
\hline Production (pieces) & 100 & $50 * * *$ & $100 * * *$ \\
\hline Sales volume (pieces) & 100 & 100 & 100 \\
\hline Final inventory position (pieces) & 50 & $0 * * *$ & $0 * * *$ \\
\hline $\begin{array}{l}\text { Production capacity } \\
\text { (pieces/period) }\end{array}$ & 100 & 100 & 100 \\
\hline $\begin{array}{c}\text { Average variable production cost } \\
(€ / \text { piece })\end{array}$ & 20 & 20 & 20 \\
\hline Fixed production costs ( $€ /$ period) & 1000 & 1000 & 1000 \\
\hline $\begin{array}{c}\text { Average fixed production cost } \\
(€ / \text { piece })\end{array}$ & 10 & 20 & 10 \\
\hline $\begin{array}{l}\text { Average production cost } \\
(€ / \text { piece })\end{array}$ & 30 & 40 & 30 \\
\hline Average price ( $€ /$ piece) & 60 & 60 & 60 \\
\hline Total production cost $(€)$ & 3000 & 2000 & 3000 \\
\hline Sales revenue $(€)$ & 6000 & 6000 & 6000 \\
\hline Cost of goods sold $(€) *$ & 3000 & $1500+2000$ & 3000 \\
\hline Initial inventory $(€)$ & 1500 & 1500 & 0 \\
\hline Final inventory $(€)$ & 1500 & 0 & 0 \\
\hline Margin $(€)$ & 3000 & 2500 & 3000 \\
\hline Overhead** $(€)$ & 2000 & 2000 & 2000 \\
\hline Profit $(€)$ & 1000 & 500 & 1000 \\
\hline
\end{tabular}

Table 1. "Calculation of the production cost after and before production adjusted to demand". Based on Olivella (2008)

Likewise, companies that have implemented lean manufacturing to a large extent find that traditional managerial accounting systems do not provide the information that managers need to make decisions (Harman \& Peterson, 1990).

It is not that traditional cost accounting is wrong. Standard costing was created in times when companies operated in a stable environment and used mass production techniques such as large batch sizes. The most important cost was direct labor and therefore other costs were allocated as a percentage of labor cost. The principles of lean manufacturing are quite different since they are oriented to competitive and changing environments, where suppliers must quickly adapt to their clients, without costly inventories that could soon become obsolete and therefore unsalable, thus using one-piece-flow plant layouts. Besides, labor cost is currently a small percentage of the total cost. 
The aim of standard costing does not depend on the production system, but the way information on costs is generated does (Tatikonda, 1988). This statement is not new: without a standardized production system as described by authors like Taylor or Ford, in the early days of the Twentieth Century, standard costing would be meaningless because each product would be different (Cooper, 2000).

Overproduction and work in process inventories have so far been considered a valuable asset, but lean philosophy considers them a waste (unnecessary consumption of resources). Traditional cost accounting and parameters like machine utilization or productivity per employee lead to decisions against lean philosophy, because, in order to achieve a minimum cost, they endorse that every section in the factory has to produce as much as possible, in large production runs and therefore keeping all sorts of inventories. Lean manufacturing focuses on manufacturing only what the customers really buy, and tries to reduce inventories, reduce cycle time and eradicate all the operations that do not add value to the products (Ward \& Graves, 2004).

Besides, accounting was created to provide financial information, not to support ongoing improvement (Harman, 1992). Harman and Peterson (1990) and Hyer and Wemmerlöv (2002) list some of the problems of traditional accounting techniques:

- Overhead cost allocation policies are not always reasonable. For example, overhead costs are allocated on the basis of direct labor costs, even though currently labor cost is a small percentage of the production (Blanco, 1988). According to Berliner and Brimson (1988) this does not seem logical. Errors in calculating labor costs are amplified.

- The recording of depreciation does not match actual asset deterioration because it is an uneven process. Assets are not appraised every year to determine their value.

- Efficiency metrics refer to internal issues that try to keep people and machines busy. They do not measure customer-related aspects (on-time delivery, quality...).

- The aim is to reach the standard cost, not to improve the process. 
- Inventories are an asset. The cost of holding items in stocks is not calculated. Traditional inventory control is not concerned with minimizing the cost of inventory. It strives to avoid inventory stock-out.

- The aim of cost accounting is to know the exact cost of a product, but changes in demand make changes in production cost because of average fixed costs (fixed cost over the number of units that are produced).

- Managers claim that they use costing to make decisions on issues like price, on order profitability or on outsourcing. On one hand, companies cannot price a product on the basis of the cost. The price is fixed by the client or there is a market price that the company must obey. Usually, an approximate cost is enough. The decision on whether to outsource or manufacture something is tricky. When a company decides to outsource part of its process, many fixed costs do not disappear - surely those fixed costs are included in the standard cost of the product and are the cause for deciding to outsource it.

A lean company cannot neglect the legally mandatory set of financial statements but may look for an accounting system that is capable of measuring operational improvements and allows the company to keep operational and financial control of the business.

Harman (1992) sums up possible accounting practices for companies which can be described as completely lean (Cuatrecasas, 2006):

- Since in lean companies raw material and work-in-process inventories are lower than in traditional companies and their fluctuations over time are also lower because of the way lean schedules production, it is not important to keep a detailed track of the inventories. They can be estimated.

- Overhead costs must not be employed to assess the goodness of the production process. However, people responsible for such costs must manage them.

- Purchases and pay slips can be used to calculate costs. Purchases are adjusted to consumption and because of practices such as long term partnership; prices do not change very often so there is no need to keep 
track of their changes. If production is adjusted to demand, pay slips equal labor costs for the produced and sold goods.

- Reports on the performance of single employees or departments are not needed anymore. Production is adjusted to demand so no one tries to do more or less work. Less non-value- added paperwork is necessary.

- Overhead costs can be allocated on labor and material cost together, not just labor. Material cost is probably more accurate. Depreciation can be allocated on the basis of the number of hours that the machines have been in use. However, the aim is to cut overhead cost, not to discuss allocation methods.

The need to review cost accounting arose in the 1980s and originated different research papers (Kaplan, 1983, 1984, 1985, 1986, 1987, 1988, 1989; Johnson \& Kaplan, 1987; Cooper \& Kaplan, 1988). The problem of the lack of adaptation of costing systems to lean manufacturing lasts till the present day (Ward, Crute, Tomkins, \& Graves, 2004; DeLuzio, 2006).

In the early days of the 21st Century, some accounting methods termed as Lean Accounting were presented, mainly removed from academic research journals Except Huntzinger and Kennedy (2005) and Maskell and Kennedy (2007)-. Those methods can be used by companies in their maturity path towards lean manufacturing (Maskell \& Baggaley, 2004). Those methods, according to the principles of lean manufacturing, focus on metrics in search of simplicity (Martínez \& Pérez, 2001). Indicators can be controlled visually and they supply useful and frequent information in order to improve processes.

Lean accounting techniques emerged in the United States. In Japan, where lean manufacturing first emerged (Tatikonda, 1988), companies use other methods such as kaizen costing or target costing (Williamson, 1997; Huntzinger, 2007).

The first answer to the problem of the lack of valid costing methods for new production paradigms was Activity-Based Costing. It was developed in 1986, on the basis of the early work done at General Electric (Johnson, 1992).

Currently many companies find that overhead costs are much more important than direct cost. $A B C$ costing was designed to reduce the distortion caused by traditional 
costing systems. It has allowed a major advance in cost accounting since costs can be allocated to the activities that cause them (Tirado, 2003), and then to object costs (products, clients, etc). In literature there is much evidence of companies that use $A B C$ as a tool to rank their opportunities to reduce costs (Jenson, Brackner, \& Skousen, 1996; Crute, Ward, Brown, \& Graves, 2003; Ward, Crute, Tomkins, \& Graves, 2003) and well-known companies continue to implement ABC costing as a tool to support continuous improvement (Balada, 1994) and to gain competitiveness (Tamarit \& Ripoll, 2006).

$A B C$ is related to full-costing methods and therefore it is very different from lean accounting, but $A B C$ allows tracking of waste of resources which is one of the pillars of lean manufacturing, and in consequence, $A B C$ costing can be used in a company independently of whether it follows the principles of lean management or not.

ABC costing has been defended by international authors (Cooper, 1994, 1996) and by specialists in lean manufacturing (Cuatrecasas, 2000). Kaplan and Cooper (1998) suggest that $A B C$ can show which improvement efforts should be given the highest priority, and help justify improvement actions from the point of view of costs while keeping track of the operational benefits. Cooper (1996) points out that $A B C$ can be compatible with lean manufacturing because it shows the causes of the costs and therefore it makes it possible to redesign the processes.

As in other case based topics, unfavorable opinions have also arisen (Anderson, 1995; Dhavale, 1996) because the system is complex, and upkeeping it requires a lot of data collection. Grasso (2005) points out that lean companies do not use ABC costing. Data collection work is a non-value-added activity and therefore it has to be avoided from the point of view of lean management (Dhavale, 1996; Plenert, 1999). Hyer and Wemmerlöv (2002) found that Activity-Based Costing can even have a boomerang effect when applied to cellular manufacturing. Huntzinger (2007) does not accept that $A B C$ can currently solve the problems caused by traditional cost accounting in lean factories, because $A B C$ operates as a full costing method. Kaplan and Anderson (2004) admit that Activity-Based Costing is very complicated and they put forward a simplification termed time driven $A B C$ to adjust the accounting system to new manufacturing paradigms. 
There is controversy about the advantages and drawbacks of $A B C$, like between direct costing and full costing, but since direct costing has not replaced full costing and both methods coexist (a recent discussion can be found in Argilés (2007)), we believe, like Banker, Barhand and Chen (2008), that companies that are starting advanced manufacturing practices such as the transition towards lean manufacturing can take advantage of some features of $A B C$, and therefore we developed a costing method for such environments.

\section{A method to start the transition towards lean manufacturing}

Maskell and Baggaley (2004) suggest that the transition towards lean accounting must be carried out in a gradual way, embodying new tools as the company introduces lean production techniques throughout its facilities. Harman (1992) suggests that the company must not wait until the lean transformation is complete to implement an accounting system that can make controlling the improvements easier. In the same way, Harman (1992) admits that in the transition it is still necessary to allocate costs to products.

For these reasons we present a practical framework to be used when starting lean manufacturing practices:

- It is based on traditional accounting practices and therefore it is easy for accountants to understand, while avoiding an outright rejection.

- It is based on Activity-Based Costing so it can help the company monitor operational improvements and discover the sources of waste. It is not necessary that the whole company adopts an $A B C$ system, which could be costly and take long. It is only a way to control the areas in transition towards lean manufacturing.

- It can be used in companies that still do not have either a global lean layout or stable lean practices and therefore cannot use advanced lean accounting techniques such as value stream costing.

This method has been developed with the intention of taking the initial steps towards lean manufacturing easier, because other accounting systems, broadly 
termed as lean accounting, only seem to be useful when the company has reached a certain degree of maturity in lean manufacturing (Ruiz de Arbulo, 2005).

Taking into account the advantages and disadvantages of Activity-Based Costing that have been discussed before, our method includes technical ratios for the expense entries of the activities (Baguer \& Zarraga, 2002) and aligns with current methodologies for the implementation of efficient production processes from the client's point of view, such as lean manufacturing (Ruiz de Arbulo, 2007).

It is not necessary to substitute, throughout the company, traditional accounting practices with our method or ABC. The company may want to use our ABC-based costing approach only for tracking the improvements in the transition towards lean manufacturing and, as the company advances, it will be able to implement other lean accounting techniques.

Our costing method can include:

- Changes in plant layout

- Changes in handling between operations

- Reductions in production run size in order to adjust to production, avoiding inventories of finished products

- Reductions in transfer lot size

- Other changes that make production more efficient and adjusted to demand

Expected cost entries are:

- Cost of raw materials and purchased components (Crm)

- Cost of activities that add value to the product (Cva)

- Cost of internal transportation (Ctran)

- Setup cost (Cset)

- Cost of work in process inventory (Cwip)

- Cost of wait time (Cwait) 
Even companies that use Activity-Based Costing calculate the final cost of the product as the summation of the costs of every single production step but, in practice, some costs such as the wait times are not considered. Since wait times and inventories are two types of "muda" that conceal deficiencies in processes (Ohno, 1988), their existence and their cost should not be ignored. Our method calculates the costs of wait time and the costs of work in process inventory. In consequence, when a new production method cuts inventories or wait times, it affects the production cost.

\subsection{Steps of the process}

Our costing method can be divided into steps:

\section{Step 1. Analysis of the process and its activities}

In Activity-Based Costing, activities are main or auxiliary tasks that when performed incur in a cost. It is necessary to know the production process in some detail in order to discover its activities. Activities can then be listed and classified:

- Activities that add value to the product (in a manufacturing company, they are operations that transform the product) or value-added activities.

- Activities that do not add value to the product from the point of view of the customer (non-value-added activities) but are currently necessary. For instance, to set a machine up, to control the production process, etc.

- Waste. Activities that do not add value to the product and are not necessary. They can be eliminated.

\section{Step 2. Determination of cost drivers}

For every activity it is necessary to have at least one cost driver. It is a measure to allocate costs, and therefore drivers must be chosen on the basis of a cause and effect relation. The greater the number of drivers there are, the more complex the system.

It is necessary to keep in mind the different sources of cost that each activity involves. The most common are materials (Resources that the activities consume in order to achieve their purposes), energy and equipment depreciation. 


\section{Step 3. Cost per driver}

When cost drivers have been selected and the different sources of cost have been considered, the cost per driver is calculated.

\section{Step 4. Cost of raw materials and purchased components ( $\mathrm{Crm}$ )}

Here we consider the amount of raw materials and components that are present in a unit of finished product. The total quantity includes the design values plus a percentage to include defects and losses in order to match current consumption of resources. Their cost is the acquisition price.

Step 5. Cost of activities that add value to the product (Cva), cost of internal transportation (Ctran), and setup cost (Cset)

According to the first step and once different types of activities have been defined, it is then the moment to calculate the cost of the value-added activities, non-valueadded-but necessary-activities and other non-value-added activities by means of equation 2, where $\mathrm{Cj}$ is the cost of product $\mathrm{j}$; Ndij is the number of drivers in activity $\mathrm{i}$ (value-added, transportation or setup) that product $\mathrm{j}$ consumes in that operation, and Cdi is the cost per driver in activity $i$.

$$
C_{j}=C_{v a_{j}}+C_{\text {tran }_{j}}+C_{s e t_{j}}=\sum_{i=1}^{n}\left[N d_{i j} \cdot C d_{i}\right]
$$

Equation 2. "Cost of activities on the basis of driver consumption".

\section{Step 6. Cost of work-in-process inventories (Cwip)}

The cost of inventories is calculated, as the product of the number of parts in inventory at each step of the production process, by the value of each part and by the holding cost. The holding cost is expressed as a percentage of the cost of the product. It is possible to calculate its value by dividing the costs associated to keeping units in inventory (warehouse depreciation, labor...) by the dollar value of the average inventory. 


\section{Step 7. Cost of wait time between processes (Cwait)}

Finally, the cost of waiting between processes is calculated. Different operations in the production process have different production rhythms. That unbalance makes parts wait between operations. Also some machines remain idle because when they finish processing a part, a new one has not arrived yet from the previous operation. This time spent waiting is considered "muda", but traditional accounting does not take it into account. To calculate this cost, it is necessary to know the wait time in each operation. In equation 3 , twait ij represents the total wait time time in activity $i$-for all units of product $j$-. CdFi is the cost of one driver of activity $\mathrm{i}$ when it is idle. $\mathrm{Nj}$ is the number of units of production $\mathrm{j}$ that are produced.

$$
C_{\text {wait (for each unit of product } j \text { ) }}=\sum_{i=1}^{n}\left[\frac{t_{\text {wait } i j} \cdot C d_{F i}}{N_{j}}\right]
$$

Equation 3. "Cost of wait time".

\section{A case study}

In order to step by step illustrate the use of the costing method and the output produced, we will next present a case study taken from a company that assembles computer peripherals. From a traditional batch-and-queue production process, this company has started to adopt lean practices in order to improve its efficiency. Namely, this case study presents an improvement in the assembly line balancing (initial values show a hard unbalance) in order to make one-piece-flow possible, which is a typical feature of lean manufacturing. Table 2 shows, for the initial situation, the different steps in the production process, the number of workstations (one for initial cleaning, three in the assembly process and one for the final packaging) and the cycle time for each workstation.

\begin{tabular}{|c|c|c|}
\hline Phase & Work post & Cycle time (s) \\
\hline Cleaning & $\mathrm{C} 1$ & 180 \\
\hline \multirow{3}{*}{ Assembling } & $\mathrm{A} 1$ & 300 \\
\cline { 2 - 3 } & $\mathrm{A} 2$ & 500 \\
\cline { 2 - 3 } & $\mathrm{A} 3$ & 820 \\
\hline Packaging & $\mathrm{P} 1$ & 200 \\
\hline
\end{tabular}

Table 2. "Description of the production process (initial method)". 


\subsection{Evaluation of the initial situation}

The initial situation can be evaluated through some key parameters that have to be calculated. Changes in the values of these parameters will be used as indicators of the results of the improvements implemented on the production line.

Monitoring parameters can be obtained from direct observation on the shop floor plus some calculations- or by means of simulation as stated by Cuatrecasas (2003, 2006) who uses an Operation-Time chart.

The main key parameters are:

- Process cycle time: this is the time elapsed between the production of two consecutive transfer lots.

- Manufacturing Lead time: this is the time necessary to manufacture the units in a production run.

- Lead time for the first unit: this is the time necessary to manufacture the first unit in a production run.

- Lead time for the last unit: this measures the time the last transfer lot is in process.

- In-process inventory (WIP): the greatest number of partially completed goods, parts or sub-assemblies that are in the different stages of the production process.

Table 3 shows the values of the different key parameters for the initial layout of the system and a production of 170 units per week.

\begin{tabular}{|c|c|c|c|c|c|}
\hline $\begin{array}{c}\text { Cycle time } \\
\text { (s) }\end{array}$ & $\begin{array}{c}\text { Total Lead } \\
\text { time (s) }\end{array}$ & $\begin{array}{c}\text { Lead time } \\
\text { lst part (s) }\end{array}$ & $\begin{array}{c}\text { Lead time } \\
\text { last part (s) }\end{array}$ & $\begin{array}{c}\text { Max WIP } \\
\text { (pieces) }\end{array}$ & $\begin{array}{c}\text { Capacity } \\
\text { (parts/ h) }\end{array}$ \\
\hline 820 & $\begin{array}{c}140,580 \\
(39.05 \\
\text { hours) }\end{array}$ & 2,000 & $\begin{array}{c}110,160 \\
(30.60 \\
\text { hours) }\end{array}$ & 136 & 4.39 \\
\hline
\end{tabular}

Table 3. "Key metrics for the initial production process". 


\subsection{I mprovements in the production process}

In the initial implementation of the production process, parts move forward with an uneven flow due to the unbalance among workstations which causes bottlenecks and work-in-process inventories. Although it is out of the scope of this work, let us remark that in order to improve the line balancing, it would be necessary to reassign tasks among employees by breaking down tasks into work elements that can then be grouped in blocks with a similar cycle time (Cuatrecasas, 1996, 2003). The way some tasks are performed may have to be redefined too. Let us assume that figure 1 shows the new assignment of tasks to workstations after the line balancing.

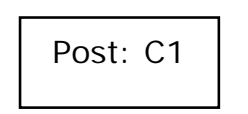

$\mathrm{T} 1=180 \mathrm{~s}$

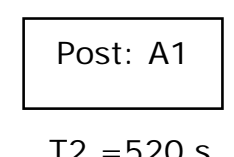

$\mathrm{T} 2=520 \mathrm{~s}$

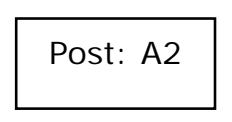

$\mathrm{T} 3=550 \mathrm{~s}$

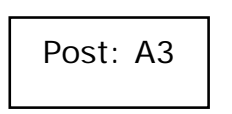

$\mathrm{T} 4=550 \mathrm{~s}$

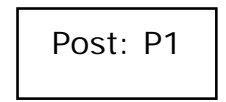

$\mathrm{T} 5=200 \mathrm{~s}$

Figure 1. "Cycle time for every work post before the line balancing".

After the line is balanced, key parameters are calculated for the new layout (Table 4) by means of simulation because the new process has not been implemented yet. Manufacturing lean time decreases by 32.5 per cent (this means a better service for customers), in-process inventory moves down from 136 to 118 pieces (it is a reduction in "muda" and in money invested); cycle time decreases around 33 per cent (reduction in "muda" and gain in speed) and total wait time also decreases to 43.3 per cent, which represents an increase in capacity.

\begin{tabular}{|c|c|c|c|c|c|}
\hline $\begin{array}{c}\text { Cycle time } \\
\text { (s) }\end{array}$ & $\begin{array}{c}\text { Total Lead } \\
\text { time (s) }\end{array}$ & $\begin{array}{c}\text { Lead time } \\
\text { 1st part (s) }\end{array}$ & $\begin{array}{c}\text { Lead time } \\
\text { last part (s) }\end{array}$ & $\begin{array}{c}\text { Max WI P } \\
\text { (pieces) }\end{array}$ & $\begin{array}{c}\text { Capacity } \\
\text { (parts/ h) }\end{array}$ \\
\hline 550 & $\begin{array}{c}94,950 \\
(26.38 \\
\text { hours) }\end{array}$ & 2,000 & $\begin{array}{c}64,530 \\
(17.93 \\
\text { hours) }\end{array}$ & 118 & 6.54 \\
\hline
\end{tabular}

Table 4. "Key metrics after balancing the production line".

\subsection{Costing the improvement}

By knowing the key parameters of the process before and after the line balancing, it is possible to calculate the cost of products in each situation by means of the methodology discussed in this paper. The necessary steps to calculate the cost are: 


\section{Choosing drivers for activities}

All activities in the production process and their drivers have been defined in table 5. In an attempt at simplicity, drivers have been named Employee-Hour (EH) and Machine-Hour (MH). Here, "Employee-Hour" means that in a specific activity, a person is performing that task for an hour and consuming all the necessary resources.

\begin{tabular}{|c|c|l|c|}
\hline Process & Activity code & \multicolumn{1}{|c|}{ Description } & Driver \\
\hline \multirow{5}{*}{ Cleaning } & CT1 & $\begin{array}{l}\text { Components necessary to manufacture 10 units of } \\
\text { finished product are taken to the cleaning area } \\
\text { (from warehouse) }\end{array}$ & EH \\
\cline { 2 - 4 } & C1 & Some parts, such as screens, need some cleaning & $\mathrm{EH}$ \\
\cline { 2 - 4 } & $\mathrm{CT} 2$ & $\begin{array}{l}\text { Parts are taken from the cleaning area to the } \\
\text { assembly line }\end{array}$ & $\mathrm{EH}$ \\
\hline \multirow{5}{*}{ Assembling } & $\mathrm{A} 1$ & Assembly line workstation 1 & $\mathrm{EH}$ \\
\cline { 2 - 4 } & $\mathrm{A} 2$ & Assembly line workstation 2 & $\mathrm{EH}$ \\
\cline { 2 - 4 } & $\mathrm{A} 3$ & Assembly line workstation 3 & $\mathrm{EH}$ \\
\hline \multirow{3}{*}{ Packaging } & AT & $\begin{array}{l}\text { Product is taken from the assembly line to the } \\
\text { packaging area }\end{array}$ & $\mathrm{EH}$ \\
\cline { 2 - 4 } & P1 & Final packaging & $\mathrm{EH}$ \\
\hline
\end{tabular}

Table 5. "Activities and cost drivers". EH: Employee-hour. MM: Machine-hour.

\section{Cost of drivers}

\begin{tabular}{|c|c|c|c|c|c|}
\hline \multicolumn{5}{|c|}{$\begin{array}{l}\text { Cost of one unit of cost driver } \\
\text { in every type of task in every activity in the process } \\
\text { (All figures are in Euros per employee-hour or machine-hour) }\end{array}$} \\
\cline { 4 - 6 } $\begin{array}{c}\text { Process } \\
\text { (Activities) }\end{array}$ & Production & \multicolumn{3}{|c|}{ Other tasks } & \multirow{2}{*}{ I dle } \\
\cline { 4 - 5 } & & & & & \\
\hline $\begin{array}{c}\text { Cleaning } \\
\text { (C1, CT1 and CT2) }\end{array}$ & 30 & 20 & 20 & 0 & 20 \\
\hline Assembly line workstation 1 (A1) & 35 & 20 & 20 & 0 & 20 \\
\hline Assembly line workstation 2 (A2) & 35 & 20 & 20 & 0 & 20 \\
\hline $\begin{array}{c}\text { Assembly line workstation 3 } \\
\text { (A3 and AT) }\end{array}$ & 35 & 20 & 20 & 0 & 20 \\
\hline $\begin{array}{c}\text { Packaging } \\
\text { (P1, PT) }\end{array}$ & 20 & 15 & 15 & 0 & 15 \\
\hline
\end{tabular}

Table 6. "Cost per unit of cost driver, according to the type of task in activity".

In this case study, the cost of each driver is in table 6. Cost depends on whether the product is being processed, transported or whether it is waiting. For example, the cost of an employee-hour is $30 €$ for a product that is being cleaned but the cost is $20 €$ for transportation because there is no consumption of materials. The last column in table 6 shows the cost of the workstation when it is idle. 


\section{Cost of raw materials and components}

The cost of raw materials and purchased components has been quantified as 10.50 $€$ per unit of finished product (Table 7 ). In the attempt at simplicity seen in the example, it is admitted that the value of the coefficient $\mathrm{Krm}$ that marks up the consumption of raw materials due to the existence of scrap in raw materials is one. Otherwise, the real consumption of raw materials would be greater than what was theoretically necessary.

\begin{tabular}{|c|c|c|c|c|c|c|c|}
\hline \multicolumn{7}{|c|}{ Calculation of the cost of raw materials and purchased components } \\
\hline Code & Description & $\begin{array}{c}\text { Purchased } \\
\text { by }\end{array}$ & $\begin{array}{c}\text { Cost } \\
(\boldsymbol{€} / \text { unit of } \\
\text { material) }\end{array}$ & UM/ UF & Krm & UM'/ UF & $\begin{array}{c}\text { Crm } \\
(\boldsymbol{€} / \mathbf{u f p})\end{array}$ \\
\hline A & Component A & Units & 2.00 & 1 & 1 & 1 & 2.00 \\
\hline B & Material B & Units & 5.50 & 1 & 1 & 1 & 5.50 \\
\hline C & Element C & Units & 3.00 & 1 & 1 & 1 & 3.00 \\
\hline \multicolumn{7}{|l}{ Total cost of raw materials and purchased parts in 1 unit of finished product } & 10.50 \\
\hline
\end{tabular}
UM/UF: Quantity of each material that is necessary (in theory) for each unit of finished product.

$\mathrm{Krm}$ : Scrap in raw materials (It might increase the consumption of raw materials).

UM'/UF: Quantity of each material that is necessary (in practice) for each unit of finished product. It is UM/UF times $\mathrm{Krm}$.

Crm: Cost of raw materials and purchased parts per unit of finished product (ufp).

Table 7. "Cost of materials and parts".

\section{Cost of work-in-process inventories}

In lean accounting it is necessary to calculate the cost of holding in-process inventories because they are considered to be a waste of resources and therefore must be avoided. In the methodology presented in this paper the cost is calculated in equation 4. The maximal quantity of units in process (WIPmax) is taken from tables 3 and 4. According to Cuatrecasas (2003), it is possible to assume that the average value is half the maximal value. Although WIP is made up of heterogeneous items (at different stages of the process) they are quantified at the production cost (CP) (see table 9). The company decides an ad valorem interest rate $(r)$ in order to meet financial and logistic costs of holding one unit per year. In our example, inventory holding costs equal one half (50 percent) of the inventory value each year. Table 8 shows the calculation of holding inventories (CWIP) per unit of manufactured product in a period $(\Theta)$, with a weekly production $(N)$ of 170 units, as stated before. 


$$
C_{W I P \theta}=\frac{\frac{W I P_{\max }}{2} \cdot C P \cdot r \cdot \theta}{N}
$$

Equation 4. "Cost of holding inventories of in-process materials".

\begin{tabular}{|c|c|c|c|c|c|c|c|}
\hline Case & $\begin{array}{c}\text { WIP } \\
\text { max } \\
\text { (pieces) }\end{array}$ & $\begin{array}{c}\text { Average } \\
\text { WIP } \\
\text { (pieces) }\end{array}$ & $\begin{array}{c}\text { Production } \\
\text { cost } \\
(€ / \text { unit) }\end{array}$ & $\begin{array}{c}\text { Rate } \\
\mathrm{r}(\%)\end{array}$ & $\begin{array}{c}\text { Time } \\
\text { (years) }\end{array}$ & $\begin{array}{c}\text { Production } \\
\text { run } \\
\text { (units) }\end{array}$ & $\begin{array}{c}\text { Cost } \\
\text { Cwip } \\
(€ / \text { ufp)* }\end{array}$ \\
\hline $\begin{array}{c}\text { Before } \\
\text { balancing }\end{array}$ & 136 & 68 & 31.40 & $50 \%$ & $1 / 50$ & 170 & 0.13 \\
\hline $\begin{array}{c}\text { After } \\
\text { balancing }\end{array}$ & 118 & 59 & 30.30 & $50 \%$ & $1 / 50$ & 170 & 0.10 \\
\hline
\end{tabular}

* In Euros per unit of finished product (ufp)

Table 8. "Calculation of the in-process inventory and its cost".

\section{Calculating the cost of production}

From the description of the initial process (see table 2 and figure 1 ) and its key metrics (Table 3 and table 4), following the steps of the costing method (Tables 5 , 6 and 7) and solving equations 2 and 3, it is possible to quantify the cost of production according to table 9. The cost of holding inventories (Equation 4 and table 8 ) is then added. Again in this example, the coefficient that measures the occurrence of defective parts $(K d)$ is set to 1 . A greater value of this coefficient would increase the quantity of resources necessary to get a valid unit of finished product, therefore increasing the production cost.

\subsection{I mprovements according to the pre-ABC costing}

From an operational point of view, thanks to a better line balancing, the average capacity of the line has improved from 4.39 parts per hour to 6.55 parts per hour and work conditions have improved because the quantity of work at each post is similar, workers have to wait less, the products flow though the stations, and workin-process inventory has decreased. But if the company used a full costing system, although the cost of each operation would be different due to the new use of labor at each post, there would be no change in the final cost, as shown in table 10.

In the current period (and in the next ones if the company takes no action), the burden is the same (because the same labor is used in the factory) despite the fact that the process is now better executed. Cost can be attributed to products and then there will be no change (as shown in table 10). In traditional cost accounting, rational apportionment of fixed cost may be used, so a part of the cost may be 
considered the cost of unused capacity. In that case (Table 11) the cost of the products would be lower but the company would still bear the rest of the burden.

\begin{tabular}{|c|c|c|c|c|c|c|c|c|}
\hline \multirow[b]{2}{*}{ Operation } & \multirow[b]{2}{*}{$\begin{array}{c}\text { Cost } \\
\text { driver }\end{array}$} & \multirow[b]{2}{*}{$\begin{array}{l}\text { Cost } \\
\text { (€/unit } \\
\text { of } \\
\text { driver) }\end{array}$} & \multicolumn{3}{|c|}{ Before balancing the process } & \multicolumn{3}{|c|}{ After balancing the process } \\
\hline & & & $\begin{array}{l}\text { Time for this } \\
\text { element } \\
\text { (s) }\end{array}$ & $\begin{array}{c}\text { Consumption of } \\
\text { drivers } \\
\text { I'/UFP }= \\
\mathrm{Kd} \cdot \mathrm{I} / \mathrm{UFP} \\
* *\end{array}$ & $\begin{array}{l}\text { Cost } \\
\text { (€/unit of } \\
\text { finished } \\
\text { product) }\end{array}$ & $\begin{array}{l}\text { Time for } \\
\text { this } \\
\text { element } \\
\text { (s) }\end{array}$ & $\begin{array}{c}\text { Consumption } \\
\text { of drivers } \\
\text { I'/UFP }= \\
\mathrm{Kd} \cdot \mathrm{I} / \text { UFP } \\
* *\end{array}$ & $\begin{array}{l}\text { Cost } \\
\text { ( } € / \text { unit of } \\
\text { finished } \\
\text { product) }\end{array}$ \\
\hline CT & $\mathrm{EH}$ & 20 & 10 & 0.0028 & 0.0556 & 10 & 0.0028 & 0.0556 \\
\hline $\mathrm{C} 1$ & $\mathrm{EH}$ & 30 & 160 & 0.0444 & 1.3333 & 160 & 0.0444 & 1.3333 \\
\hline $\mathrm{CT}$ & $\mathrm{EH}$ & 20 & 10 & 0.0028 & 0.0556 & 10 & 0.0028 & 0.0556 \\
\hline $\begin{array}{l}\text { Wait } \\
\text { Al }\end{array}$ & & 20 & 180 & $\begin{array}{c}\text { Average on } 170 \\
\text { units }\end{array}$ & 0.0059 & 180 & $\begin{array}{l}\text { Average on } \\
170 \text { units }\end{array}$ & 0.0059 \\
\hline $\mathrm{A} 1$ & $\mathrm{EH}$ & 35 & 300 & 0.0833 & 2.9167 & 520 & 0.1444 & 5.0556 \\
\hline $\begin{array}{l}\text { Wait } \\
\text { A2 }\end{array}$ & & 20 & 480 & $\begin{array}{c}\text { Average on } 170 \\
\text { units }\end{array}$ & 0.0157 & 700 & $\begin{array}{l}\text { Average on } \\
170 \text { units }\end{array}$ & 0.0229 \\
\hline $\mathrm{A} 2$ & $\mathrm{MH}$ & 35 & 500 & 0.1389 & 4.8611 & 550 & 0.1528 & 5.3472 \\
\hline $\begin{array}{l}\text { Wait } \\
\text { A3 }\end{array}$ & & 20 & 980 & $\begin{array}{c}\text { Average on } 170 \\
\text { units }\end{array}$ & 0.0320 & 1,250 & $\begin{array}{l}\text { Average on } \\
170 \text { units }\end{array}$ & 0.0408 \\
\hline A3 & $\mathrm{EH}$ & 35 & 810 & 0.2250 & 7.8750 & 540 & 0.1500 & 5.2500 \\
\hline AT & $\mathrm{EH}$ & 20 & 10 & 0.0028 & 0.0556 & 10 & 0.0028 & 0.0556 \\
\hline $\begin{array}{l}\text { Wait } \\
\text { P1 }\end{array}$ & & 15 & 106,580 & $\begin{array}{c}\text { Average on } 170 \\
\text { units }\end{array}$ & 2.6123 & 60,950 & $\begin{array}{l}\text { Average on } \\
170 \text { units }\end{array}$ & 1.4939 \\
\hline P1 & $\mathrm{EH}$ & 20 & 180 & 0.0500 & 1.0000 & 180 & 0.0500 & 1.0000 \\
\hline PT & $\mathrm{EH}$ & 15 & 20 & 0.0056 & 0.0833 & 20 & 0.0056 & 0.0833 \\
\hline \multicolumn{3}{|c|}{$\begin{array}{c}\text { Cost of activities } * \\
\text { In production processes }\end{array}$} & \multicolumn{3}{|r|}{20.90} & \multicolumn{3}{|r|}{19.80} \\
\hline \multicolumn{3}{|c|}{$\begin{array}{c}\text { Cost of raw materials Crm } \\
(\text { Table } 7) *\end{array}$} & \multicolumn{3}{|c|}{10.50} & \multicolumn{3}{|c|}{10.50} \\
\hline \multicolumn{3}{|c|}{ Total cost of production CP } & \multicolumn{3}{|r|}{31.40} & \multicolumn{3}{|r|}{30.30} \\
\hline \multicolumn{3}{|c|}{$\begin{array}{c}\text { Cost of in-process } \\
\text { inventories Cwip } \\
(\text { Table } 8)^{*}\end{array}$} & \multicolumn{3}{|c|}{0.13} & \multicolumn{3}{|c|}{0.10} \\
\hline \multicolumn{3}{|c|}{ Total cost of the product $*$} & \multicolumn{3}{|r|}{31.53} & \multicolumn{3}{|r|}{30.40} \\
\hline
\end{tabular}

$*$ In Euros per unit of finished product

** Quantity of cost driver consumed by the activity per unit of finished product. The empirical quantity I' equals the theoretical quantity I because the coefficient $\mathrm{Kd}$ that takes into account the production of defectives is set to 1 (no defectives).

Table 9. "Calculation of the production cost, according to the costing method based on ABC".

\begin{tabular}{|c|c|c|c|c|c|c|c|c|}
\hline \multirow{2}{*}{$\begin{array}{c}\text { FULL } \\
\text { COSTING }\end{array}$} & \multicolumn{4}{|c|}{ Before line balancing } & \multicolumn{4}{c|}{ After line balancing } \\
\cline { 2 - 9 } & $\begin{array}{c}\text { Fixed } \\
\text { cost }\end{array}$ & $\begin{array}{c}\text { Variable } \\
\text { cost }\end{array}$ & $\begin{array}{c}\text { Total } \\
\text { cost }\end{array}$ & $\begin{array}{c}\text { Cost per } \\
\text { unit }\end{array}$ & $\begin{array}{c}\text { Fixed } \\
\text { cost }\end{array}$ & $\begin{array}{c}\text { Variable } \\
\text { cost }\end{array}$ & $\begin{array}{c}\text { Total } \\
\text { cost }\end{array}$ & $\begin{array}{c}\text { Cost per } \\
\text { unit }\end{array}$ \\
\cline { 2 - 9 } Material & $(€)$ & $(€)$ & $(€)$ & $(€ /$ unit) & $(€)$ & $(€)$ & $(€)$ & $(€ /$ unit) \\
\hline C & 780,00 & 75,56 & 855,56 & 5,03 & 780,00 & 75,56 & 855,56 & 5,03 \\
\hline A1 & 780,00 & 212,50 & 992,50 & 5,84 & 780,00 & 368,33 & 1148,33 & 6,75 \\
\hline A2 & 780,00 & 354,17 & 1134,17 & 6,67 & 780,00 & 389,58 & 1169,58 & 6,88 \\
\hline A3 & 780,00 & 573,75 & 1353,75 & 7,96 & 780,00 & 382,50 & 1162,50 & 6,84 \\
\hline P & 585,00 & 42,50 & 627,50 & 3,69 & 585,00 & 42,50 & 627,50 & 3,69 \\
\hline Total cost & & & 4963,47 & 39,70 & & & 4963,47 & 39,70 \\
\hline
\end{tabular}

Table 10. "Calculation of the production cost, according to Full costing". Variable cost is calculated on the average time devoted to each part before and after balancing the line. 
While in table 2 there is a reduction in production, in tables 9 and 10 the number of parts assembled is the same as usual, so in practice the company would probably fail to appreciate the change in capacity and therefore would never consider table 11. In future periods, the company may be able to adjust the amount of labor or may produce more (if demand increases), but in the present, accounting is not able to anticipate future profits (Olivella, 2008).

\begin{tabular}{|c|c|c|c|c|}
\hline \multirow{2}{*}{ APPORTIONMENT } & \multicolumn{4}{|c|}{ After line balancing } \\
\cline { 2 - 5 } & $\begin{array}{c}\text { Fixed } \\
\text { cost }\end{array}$ & $\begin{array}{c}\text { Variable } \\
\text { cost }\end{array}$ & $\begin{array}{c}\text { Total } \\
\text { cost }\end{array}$ & $\begin{array}{c}\text { Cost per } \\
\text { unit }\end{array}$ \\
\cline { 2 - 5 }$(€)$ & $(€)$ & $(€)$ & $(€ /$ unit $)$ \\
\hline Material & & & & 10,50 \\
\hline C & 519,44 & 75,56 & 595,00 & 3,50 \\
\hline A1 & 519,44 & 368,33 & 887,78 & 5,22 \\
\hline A2 & 519,44 & 389,58 & 909,03 & 5,35 \\
\hline A3 & 519,44 & 382,50 & 901,94 & 5,31 \\
\hline P & 389,58 & 42,50 & 432,08 & 2,54 \\
\hline Total cost & & & 3725,83 & 32,42 \\
\hline
\end{tabular}

Table 11. "Calculation of the production cost when apportionment is used".

\section{Conclusions}

There is evidence in literature that the adoption of the lean manufacturing paradigm brings about improvements in productivity, quality and delivery figures. In consequence, many companies implement lean manufacturing techniques.

These companies hope that lean techniques will bring better operational performance that can be measured as a decrease in cost. However, while operational improvements are evident sometimes they do not seem to lead to reduced costs. Since this seemed strange, it was discovered that traditional costing methods were not suitable for lean production.

This is because cost accounting was created to support mass production, just like other performance indicators such as machine utilization, which are based on the paradigm of mass production. This paradigm fixes the behavior which is good, and which actions are wrong in order to adapt to a certain environment. The paradigm of lean production is completely different and was created to face a very different environment; conventional cost accounting cannot meet the requirements of lean manufacturing and discourages lean implementations. 
The example in table 1 showed that the adoption of certain manufacturing practices, despite their operational advantages, may convey, at least in the short run, costs (instead of cutting them) and losses that may discourage managers. If rational apportionment of fixed cost is used, it is possible to better understand the causes of the cost and not to allocate it to products; however, the final result is the same.

Changes towards lean manufacturing such as cellular manufacturing make cost management easier because each product (or family) has a distinct flow and there are not many variations from time to time in the production process. There are also not many units in inventory. This allows some simplifications that have been termed lean accounting.

However, there is no agreement on how accounting practices should be adopted and developed to support lean manufacturing. There is no relevant academic literature on this topic.

Lean accounting is suitable for companies that have implemented lean manufacturing to a certain extent. The company may then implement further lean accounting techniques along with new lean manufacturing practices, but there is no "non traditional" accounting method for companies that have just started the transformation to lean manufacturing. For this reason, this paper presents an accounting method based on Activity-Based Costing that can calculate the cost of products, the cost of waste (such as waiting) and the savings of operational improvements.

$A B C$ has been chosen because that method came about in order to support companies that did not fit the mass production paradigm. Although ABC consumes many resources for data collection (and this is contrary to the principles of lean management), it includes the concept of production flow and helps reveal sources of waste (activities that can be considered a waste of resources) and its effect (cost) on products. Its ideas are of flow, waste reduction, ongoing improvement and target cost which are central to the paradigm of lean manufacturing.

Moreover, although it is possible, it is not necessary to change the whole current costing system if the company does not feel confident doing so. Our method can be used just to evaluate the improvements on the areas that are implementing 
aspects of lean manufacturing. Once the implementation of lean manufacturing progresses, other lean accounting techniques may be implemented.

The application of our costing method has been presented by means of a simple example. Without being foreign to traditional costing (similar to time-driven $A B C$ because drivers are based on time), it has shown the cost of the activities, its effect on the product and the savings conveyed by the operational improvement. With the help of the costing method presented in this paper, the operational improvement is related to an improved cost.

Table 9 shows a comparison between the cost of the product in the initial situation and once the process is more efficient. After balancing the production process, the cost of value added and transportation activities has not changed because the time of the operations is the same, as well as the cost of the drivers. However, the cost of wait time and the cost of holding inventories have diminished because these are the main improvements introduced by a line balancing.

In many companies, traditional accounting does not consider such costs and therefore the improvement would be irrelevant from the point of view of cost (as seen in Table 10). The capacity has increased, and in the future it can be very positive for the company, but accounting does not measure future profits. If the company uses apportionment of costs, then part of the cost can be described as the cost of unused capacity and not be allocated to products; but since capacity is measured in volume and the production of parts in our example is the same as usual, the company would probably never notice a change in capacity or cost.

\section{References}

Ahlström, P., \& Karlsson, C. (1996). Change processes towards lean production: the role of the management accounting system. International journal of operations \& production management, 16(11), 42-56.

doi: $10.1108 / 01443579610131447$

Anderson, S. W. (1995). A Framework for Assessing Cost Management Systems: The Case of Activity Based Costing Implementation at General Motors, 19861993. J ournal of Management Accounting Research, 7(Fall), 1-51. 
Argilés Bosch, J. M. (2007). Análisis del comportamiento de los resultados en "full" y "direct costing". Cuadernos de CC.EE y EE., 53, 107-133.

Baguer, A., \& Zárraga, M. (2002). Dirige. Manual de conceptos prácticos y necesarios para la gestión empresarial. Madrid: Ed. Diaz de Santos.

Balada Ortega, T. (1994). El rediseño de procesos en el contexto de la contabilidad de gestión: prácticas y experiencias en Ford España S.A., In J. Lizcano (coordinator), Elementos de Contabilidad de Gestión. Madrid: Ediciones Asociación Española de Contabilidad y Administración de Empresas.

Banker, R. D., Bardhan, I.R., \& Chen, T.Y. (2008). The role of manufacturing practices in mediating the impact the impact of activity-based costing on plant performance. Accounting, organizations and society, 3, 1-19.

doi: 10.1016/j.aos.2006.12.001

Berliner, C., \& Brimson, J.A. (1988). Cost management for today's advanced manufacturing: The CAM-I conceptual design. Boston: Harvard Business School Press.

Blanco I barra, F. (1988). Curso de contabilidad analítica. Bilbao: Ediciones Deusto.

Cooper, R. (1994). The role of Activity-based system in supporting the transition to the lean enterprise". Advances in Management Accounting; Research annual, 3, $1-24$.

Cooper, R. (1996). Activity-based costing and the lean enterprise. J ournal of Cost Management (Winter), 6-14.

Cooper, R. (2000). Cost management: from Frederick Taylor to the present. J ournal of Cost Management, (September/October), 4-9.

Cooper, R., \& Kaplan, R.S. (1988). Measure costs right: make the right decisions. Harvard Business Review, (September-October), 96-103.

Crute, V., Ward, Y., Brown, S., \& Graves, A. (2003). Implementing Lean in Aerospace - challenging the assumptions and understanding the challenges. Technovation, (23) 917-928.

doi: 10.1016/S0166-4972(03)00081-6 
Cuatrecasas Arbós, L. (1996). Diseño de procesos de producción flexible. Madrid: TGP-Productivity Press.

Cuatrecasas Arbós, L. (2000). Organización de la producción y dirección de operaciones. Sistemas actuales de gestión eficiente y competitiva. Madrid: Ed. Centro de estudios Ramón Areces.

Cuatrecasas Arbós, L. (2003). Gestión competitiva de stocks y procesos de producción. Barcelona: Ed. Gestión 2000.

Cuatrecasas Arbós, L. (2006). Claves de Lean Management. Barcelona: Ed. Gestión 2000.

DeLuzio, M.C. (2006). Accounting for lean - Conventional accounting must adapt to accommodate the lean movement. Manufacturing engineering, 137(6), 83.

Dhavale, D.G. (1996). Performance Measures for Cell Manufacturing and /Focused Factory Systems. J ournal of Cost Management, 10(1), 59-69.

Goldratt, E. M., \& Cox, J. (1986). The Goal: A process of ongoing improvement. New York: North River Press.

Grasso, L.P. (2005). Are $A B C$ and RCA accounting systems compatible with lean management. Management accounting quarterly, 7(1), 12-27.

Harman, R. L. (1992). Reinventing the factory II. Managing the world class factory. New York: The Free Press, New York.

Harman R. L., \& Peterson, L.D. (1990). Reinventing the Factory: Productivity Breakthroughs in Manufacturing Today. New York: The Free Press.

Hyer, N. L., \& Wemmerlöv, U. (2002). Reorganizing the factory: competing through cellular manufacturing. Portland: Productivity Press.

Huntzinger, J. R. (2007). Lean cost management: accounting for lean by establishing flow. San Francisco: J. Ross Publishing.

Huntzinger, J., \& Kennedy, F.A. (2005). Lean accounting: measuring and managing the value stream. Journal of cost management, 19(5), 31-38. 
Jenson, R., Brackner, J., \& Skousen, C. (1996). Management accounting in support of manufacturing excellence. Montvale: Institute of Management Accountants.

Johnson, H.T., \& Kaplan, R.S. (1987). Relevance Lost- The rise and fall of management accounting. Boston: Harvard Business School Press.

Johnson, H.T. (1992). Relevance Regained: from ttop-down control to bottom-up empowerment. New York: The Free Press Business.

Kaplan, R. S. (1983). Measuring manufacturing performance: a new challenge for managerial accounting research. The accounting review, 58(4), 686-705.

Kaplan, R. S. (1984). Yesterday's accounting undermines production. Harvard Business Review, 62(July-August), 95-101.

Kaplan, R.S. (1985). Una contabilidad anticuada puede socavar la producción. Harvard Deusto Business Review, (23), 125-134.

Kaplan, R.S. (1986). Accounting lag: The obsolescence of cost accounting systems. California Management Review, 18(2), 174-199.

Kaplan, R.S. (1987). Regaining Relevance. In R. Capettine, R. \& D.K. Clancy (Ed.), Cost Accounting, Robotics, and the New Manufacturing Environment. Sarasota: American Accounting Association.

Kaplan, R.S. (1988). One cost system isn't enough. Harvard Business Review 66(January-February), 61- 66.

Kaplan, R.S. (1989). Limitations of Cost Accounting in Advanced Manufacturing Environments. Colloquium. Cambridge (MA.): Harvard Business School, Cambridge.

Kaplan, R.S, \& Anderson, S.R. (2004). Time driven activity-based costing. Harvard Business Review, 82(11), 131-138.

Kaplan R.S., \& Cooper, R. (1998). Cost and Effect. Boston: Harvard Business School Press.

Martínez Sánchez, A., \& Pérez Pérez, M. (2001). Lean indicators and manufacturing strategies. International Journal of Operations \& Production Management, 21(11), 
1433-1451.

doi: $10.1108 / 01443570110407436$

Maskell, B.H., \& Baggaley, B. (2004). Practical lean accounting. A proven system for measuring and managing the lean enterprise. New York: Productivity Press.

Maskell, B.H., \& Kennedy, F.A. (2007). Why Do We Need Lean Accounting and How Does It Work? The Journal of Corporate Accounting \& Finance, (March/April), 5973.

doi: $10.1002 /$ jcaf. 20293

Ohno, T. (1988). Toyota Production System: Beyond Large-Scale Production. Cambridge (MA.): Productivity Press.

Olivella Nadal, J. (2008): Los beneficios de las empresas durante la implantación del lean. Retrieved August $29^{\text {th }}, 2009$, from http://www.institutolean.org/articulos/articulos_ilm_0803_olivella.pdf.

Plenert, G. (1999). The new manufacturing-accounting interface. Industrial management and data systems, 99(1), 25-32.

doi: $10.1108 / 02635579910249891$

Ruiz de Arbulo López, P. (2005). Un nuevo modelo de gestión de costes para avanzar hacia la producción lean (Doctoral dissertation). Universidad del País Vasco.

Ruiz de Arbulo López, P. (2007). La gestión de costes en lean manufacturing. La Coruña: NetBiblo.

Sriparavastu, L., \& Gupta, T. (1997). An empirical study of just-in-time and total quality management principles implementation in manufacturing firms in the USA. International Journal of Operations \& Production Management, 17(12), 12151232.

\section{doi: $10.1108 / 01443579710182954$}

Sugimori, Y., Kusunoki, K., Cho, F., \& Uchikawa, S (1977). Toyota production system and Kanban system. Materialization of just-in-time and respect-for-human system. International J ournal of Production Research, 15(6), 553-564. doi: $10.1080 / 00207547708943149$ 
Tamarit Aznar, M.C., \& Ripoll Feliu, V.M. (2006). Implantación del ABC/ABM en RENFE. Revista de contabilidad y dirección, (3), 197-208.

Tatikonda, M. V. (1988). Just-in-time and modern manufacturing environments: implications for cost accounting. Production and inventory management journal, (First quarter), 1-5.

Tirado Valencia, P. (2003). Gestión de costes y mejora continua. Los sistemas de costes y de gestión basados en las actividades (ABC-ABM). Bilbao: Ed. Desclée de Brouwer.

Ward, Y., \& Graves, A. (2004). A new cost manufacturing and accounting approach for lean enterprises. (Working paper series, 5). University of Bath School of management.

Ward, Y., Crute, V., Tomkins, C., \& Graves, A. (2003). Cost management and accounting methods to support lean aerospace enterprises. A UK Lean Aerospace initiative Report, University of Bath.

Ward, Y., Crute, V., Tomkins, C., \& Graves, A. (2004). Costing for Competitiveness: Cost Management and Accounting for Lean Enterprises. Society of British Aerospace Companies Publication.

Williamson, A. (1997). Target and kaizen costing. Manufacturing engineer, 76(1), 22-24.

Womack, J. P., \& Jones, D. T. (1996). Lean thinking: banish waste and create wealth in your corporation. New York: The Free Press.

Womack J. P., Jones D.T., \& Ross, D. (1990). The machine that changed the world. New York: The Free Press. 
Journal of Industrial Engineering and Management, 2010 (www.jiem.org)

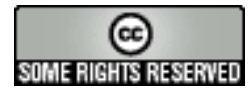

Article's contents are provided on a Attribution-Non Commercial 3.0 Creative commons license. Readers are allowed to copy, distribute and communicate article's contents, provided the author's and Journal of Industrial Engineering and Management's names are included. It must not be used for commercial purposes. To see the complete license contents, please visit http://creativecommons.org/licenses/by-nc/3.0/. 